\title{
Mating ability of homo- and heterokaryotypes of Drosophila ananassae from natural populations
}

\author{
B. N. Singh and Sujata Chatterjee
}

Genetics Laboratory, Department of Zoology, Banaras Hindu University, Varanasi-221 005, India.

Mating ability of homo- and heterokaryotypes due to the subterminal (alpha or In (2L)A) inversion in $2 \mathrm{~L}$ chromosome of Drosophila ananassae from three different natural populations has been studied. The data indicate that the average number of females inseminated by a given male varies for different karyotypes in males and the analysis of variance shows that the differences are highly significant for males in the three populations studied. However, the averages for different karyotypes in females show less variation as compared to males. Thus a striking sex difference exists in $D$. ananassae. The comparison of mating activity with gene arrangement frequencies in natural populations indicates that the gene arrangement occurring in high frequency is associated with greater mating propensity. These findings suggest that chromosomal polymorphism in $D$. ananassae may have a partial behavioural basis and males are more subject to intrasexual selection than females.

\section{INTRODUCTION}

From previous reports on sexual behaviour in the genus Drosophila, it is clear that the efficiency of mating varies for different genotypes (Rendel, 1944; Bastock, 1956; Smith, 1958; Parsons, 1973; Petit, 1958; Bosiger, 1962). Selection for fast and slow mating speed in Drosophila melanogaster suggests polygenic control of this trait (Manning, 1961). Spiess and Langer (1961) demonstrated for the first time the association between mating propensity and chromosomal polymorphism in D.persimilis. The correlation between inversion polymorphism and mating activity has also been shown in D. pseudoobscura (Spiess and Langer, 1964b; Spiess et al., 1966; Kaul and Parsons, 1965; Parsons and Kaul, 1966), D. pavani (Brncic and KorefSantibanez, 1964), D. subobscura (Sperlich, 1966) and D. robusta (Prakash, 1968). The observed frequencies of different chromosomes in natural populations parallel their mating propensities in $D$. persimilis (Spiess and Langer, 1964a) and $D$. pseudoobscura (Spiess and Langer, 1964b). Ehrman and co-workers (Ehrman, 1966, 1970; Ehrman and Petit, 1968) observed mating advantage of rare genotypes for mutants and gene arrangements in some species of Drosophila. Prakash (1968) presented evidence for chromosome interaction effecting mating speed in $D$. robusta.
Drosophila ananassae, a cosmopolitan domestic species, has a high degree of chromosomal variability (for references, see Singh, 1982). The Indian natural populations of this species are genetically differentiated at the level of chromosomal polymorphism (Singh, 1974, 1984a, 1984b, $1984 c, 1985 a, 1985 b$ ). The subterminal (alpha or In (2L)A) inversion has become universally established in the species (Shirai and Moriwaki, 1952; Futch, 1966; Singh, 1970). The inversion heterozygotes exhibit heterosis (Moriwaki et al., 1956; Kojima and Tobari, 1969; Singh and Ray-Chaudhuri, 1972; Singh, 1982). However, the degree of heterosis varies in different strains and intra- and inter-populations crosses (Singh, 1985c and earlier). Since it is known that behavioural properties are controlled by naturally occurring chromosomal variants, it seemed worthwhile to investigate the mating ability of homo- and heterokaryotypes from natural populations with a view toward understanding the relation between mating behaviour and chromosomal polymorphism in $D$. ananassae.

\section{MATERIALS AND METHODS}

During the present study, three natural populations were sampled: 
(a) Ghazipur (Uttar Pradesh)_-Flies were collected in October, 1984. The data on inversion frequencies based on August and October 1984 samples have been described elsewhere (Singh, $1985 b)$.

(b) Varanasi (Uttar Pradesh)_-Flies were collected in October, 1984. The frequencies of inversions in this population are known (Singh 1984a).

(c) Madras (Tamil-Nadu)_-Flies were collected in December 1984. The data on inversion frequencies have been reported separately (Singh, 1985b).

From the descendants of freshly collected females in each of the three populations, two homozygous stocks (one for ST and the other for AL in $2 \mathrm{~L}$ ) were prepared and used in the experiments. For randomisation of genetic background and to have genetic control over fitness properties, different lines of each chromosome type were crossed with each other and two stocks of homokaryotypes, ST/ST and AL/AL were set up for each population. In order to obtain the flies heterozygous for inversion, both these stocks were crossed by making reciprocal crosses. ST/AL heterozygotes were produced by crossing ST/ST females and AL/AL males and AL/ST heterozygotes produced by crossing $\mathrm{AL} / \mathrm{AL}$ females with ST/ST males. Virgin females and males of different karyotypes, ST/ST, ST/AL, AL/ST and AL/AL were collected and aged for 7 days. To measure the mating ability of each karyotypic male to inseminate a number of females, a single male with six females of uniform karyotype were kept in a $3 \times 1$ in. food vial for 12 hours at approximately $24^{\circ} \mathrm{C}$ temperature. After exposing the females to the male for 12 hours, they were separated and dissected in saline solution. Their reproductive tracts (vagina, spermathecae and ventral receptacles) were examined for the presence of sperm. In total 16 combinations were made and in each combination 30 males were tested in each of the three populations.

\section{RESULTS}

The average number of females inseminated by a single male in a 12 hour period is shown separately for different populations. Table 1 presents the data on the average number of females inseminated by a single male for homo- and heterokaryotypes from Ghazipur population. It is evident from the results that the heterozygous males mate more frequently than either homozygote, ST/ST or AL/AL. The average number of females inseminated by a single male heterozygous for inversion is 4.15 for ST/AL and 4.02 for AL/ST. The average for ST/ST males is 2.82 and for AL/AL males is 2.55 . The average range for females is from 3.32 (ST/AL) to 3.52 $(\mathrm{ST} / \mathrm{ST})$. Between two homozygotes, ST/ST is superior to AL/AL for both male and female karyotypes. The analysis of variance is given in table 2 and shows that the differences are highly significant for different karyotypes in males $(F=$ $41 \cdot 77, P<0.005)$. However, the differences among the averages for female karyotypes are not significant $(F=0.56 ; P>0.25)$. In the Ghazipur population, the chromosomes with ST gene order are more frequent than those with $\mathrm{AL}$ gene sequence.

The data on mating ability of males with different karyotypes from Varanasi population are given in table 3 . The averages for male karyotypes range from $1.47(\mathrm{AL} / \mathrm{AL})$ to $2.45(\mathrm{ST} / \mathrm{ST})$. The males homozygous for ST gene sequence and heterozygous for AL inversion inseminate nearly equal number of females. The AL/AL males have low mating propensity as compared to ST/ST homozygotes and heterozygotes. The average for female karyotypes varies from 1.99 (AL/AL) to $2 \cdot 25$ (ST/ST). Thus AL/AL females mate less readily than ST/ST and heterozygous females. The analysis of variance given in table 4 shows that the differences are highly significant for males $(F=$ $20 \cdot 46, P<0 \cdot 005)$ but insignificant for females $(F=$ $1 \cdot 30, P>0 \cdot 25)$. In the Varanasi population, the frequency of ST chromosomes is higher than those of AL chromosomes.

Table 1 Average number of females inseminated by a single male in a 12 hour period (Ghazipur population)

\begin{tabular}{|c|c|c|c|c|c|}
\hline$\delta$ & $\mathrm{ST} / \mathrm{ST}$ & $\mathrm{ST} / \mathrm{AL}$ & $\mathrm{AL} / \mathrm{ST}$ & $\mathrm{AL} / \mathrm{AL}$ & $\begin{array}{l}\text { Average } \\
\text { for } \\
\text { females }\end{array}$ \\
\hline $\mathrm{ST} / \mathrm{ST}$ & $3 \cdot 40$ & $4 \cdot 17$ & $4 \cdot 13$ & $2 \cdot 40$ & $3 \cdot 52$ \\
\hline $\mathrm{ST} / \mathrm{AL}$ & $2 \cdot 50$ & $4 \cdot 20$ & 3.97 & $2 \cdot 60$ & $3 \cdot 32$ \\
\hline $\mathrm{AL} / \mathrm{ST}$ & $2 \cdot 70$ & $4 \cdot 30$ & $3 \cdot 77$ & $2 \cdot 60$ & $3 \cdot 34$ \\
\hline $\mathrm{AL} / \mathrm{AL}$ & $2 \cdot 70$ & $3 \cdot 93$ & $4 \cdot 23$ & $2 \cdot 60$ & $3 \cdot 36$ \\
\hline $\begin{array}{l}\text { Average } \\
\text { for } \\
\text { males }\end{array}$ & $2 \cdot 82$ & $4 \cdot 15$ & $4 \cdot 02$ & $2 \cdot 55$ & \\
\hline
\end{tabular}

Table 2 Analysis of variance

\begin{tabular}{lrll}
\hline $\begin{array}{l}\text { Source } \\
\text { variation }\end{array}$ & df & $\begin{array}{l}\text { Sum of } \\
\text { squares }\end{array}$ & $\begin{array}{l}\text { Mean } \\
\text { square }\end{array}$ \\
\hline Male karyotypes & 3 & 8.02 & 2.673 \\
Female karyotypes & 3 & 0.11 & 0.036 \\
Error & 9 & 0.58 & 0.064 \\
Total & 15 & 8.71 & \\
\hline
\end{tabular}

For males: $F=41.77 ; P<0.005$

For females: $F=0.56 ; P>0.25$. 
Table 3 Average number of females inseminated by a single male in a 12 hour period (Varanasi population)

\begin{tabular}{|c|c|c|c|c|c|}
\hline$\sigma$ & $\mathrm{ST} / \mathrm{ST}$ & ST/AL & $\mathrm{AL} / \mathrm{ST}$ & $\mathrm{AL} / \mathrm{AL}$ & $\begin{array}{l}\text { Average } \\
\text { for } \\
\text { females }\end{array}$ \\
\hline $\mathrm{ST} / \mathrm{ST}$ & $2 \cdot 63$ & $2 \cdot 60$ & $2 \cdot 53$ & $1 \cdot 23$ & $2 \cdot 25$ \\
\hline ST/AL & $2 \cdot 43$ & $2 \cdot 40$ & $2 \cdot 43$ & $1 \cdot 56$ & $2 \cdot 20$ \\
\hline $\mathrm{AL} / \mathrm{ST}$ & 2.63 & $2 \cdot 36$ & $2 \cdot 17$ & 1.82 & $2 \cdot 24$ \\
\hline $\mathrm{AL} / \mathrm{AL}$ & $2 \cdot 13$ & $2 \cdot 19$ & $2 \cdot 40$ & $1 \cdot 26$ & 1.99 \\
\hline Average & & & & & \\
\hline for males & $2 \cdot 45$ & $2 \cdot 39$ & $2 \cdot 38$ & 1.47 & \\
\hline
\end{tabular}

Table 4 Analysis of variance

\begin{tabular}{lcll}
\hline $\begin{array}{l}\text { Source of } \\
\text { variation }\end{array}$ & d.f. & $\begin{array}{l}\text { Sum of } \\
\text { squares }\end{array}$ & $\begin{array}{l}\text { Mean } \\
\text { square }\end{array}$ \\
\cline { 3 - 4 } Male karyotypes & 3 & 2.65 & 0.88 \\
Female karyotypes & 3 & 0.17 & 0.056 \\
Error & 9 & 0.39 & 0.043 \\
Total & 15 & 3.21 & \\
\hline
\end{tabular}

For males: $F=20.46 ; P<0.005$

For females: $F=1 \cdot 30 ; P>0.250$.

Table 5 incorporates the data on the average number of females inseminated by a single male with different karyotypes from the Madras population. The averages for different karyotypic males range from 1.69 (ST/ST) to 3.11 (AL/AL). Thus AL/AL males inseminate more females than ST/ST males from the same population. The averages for females show less variation than males but AL/AL females mate more readily than ST/ST females. The analysis of variance given in table 6 shows that the differences are highly significant for male karyotypes $(F=91.25, \quad P<0.005)$. The differences are also significant for female karyotypes but at lower level than males $(F=11 \cdot 25$, $P<0.005)$. With respect to the gene arrangement frequencies, the Madras population is different from the Ghazipur and Varanasi populations. The standard chromosomes occur with lower frequency than the AL chromosomes in the Madras population.

Table 5 Average number of females inseminated by a single male in a 12 hour period (Madras population)

\begin{tabular}{|c|c|c|c|c|c|}
\hline$\sigma$ & $\mathrm{ST} / \mathrm{ST}$ & ST/AL & $\mathrm{AL} / \mathrm{ST}$ & $\mathrm{AL} / \mathrm{AL}$ & $\begin{array}{l}\text { Average } \\
\text { for } \\
\text { females }\end{array}$ \\
\hline $\mathrm{ST} / \mathrm{ST}$ & $1 \cdot 23$ & $2 \cdot 40$ & $2 \cdot 60$ & $2 \cdot 70$ & $2 \cdot 23$ \\
\hline ST/AL & $2 \cdot 00$ & $2 \cdot 86$ & $2 \cdot 73$ & $3 \cdot 23$ & $2 \cdot 70$ \\
\hline $\mathrm{AL} / \mathrm{ST}$ & $1 \cdot 86$ & $2 \cdot 76$ & $2 \cdot 80$ & $3 \cdot 20$ & $2 \cdot 65$ \\
\hline $\mathrm{AL} / \mathrm{AL}$ & $1 \cdot 66$ & $2 \cdot 63$ & $2 \cdot 70$ & $3 \cdot 30$ & $2 \cdot 57$ \\
\hline $\begin{array}{l}\text { Average } \\
\text { for males }\end{array}$ & $1 \cdot 69$ & $2 \cdot 66$ & $2 \cdot 70$ & $3 \cdot 11$ & \\
\hline
\end{tabular}

Table 6 Analysis of variance

\begin{tabular}{lrll}
\hline $\begin{array}{l}\text { Source of } \\
\text { variation }\end{array}$ & d.f. & $\begin{array}{l}\text { Sum of } \\
\text { squares }\end{array}$ & $\begin{array}{l}\text { Mean } \\
\text { square }\end{array}$ \\
\hline Male karyotypes & 3 & $4 \cdot 37$ & $1 \cdot 46$ \\
Female karyotypes & 3 & $0 \cdot 55$ & $0 \cdot 18$ \\
Error & 9 & $0 \cdot 15$ & 0.016 \\
Total & 15 & $5 \cdot 07$ & \\
\hline
\end{tabular}

For Males: $F=91.25 ; P<0.005$.

For Females: $F=11.25 ; P<0.005$.

\section{DISCUSSION}

It is known that male activity and female receptivity are the main factors responsible for successful mating in Drosophila (Bateman, 1948; Spieth, 1952; Bastock, 1956). The males which inseminate more females in a limited time will contribute more progeny (Spiess and Langer, 1961). In D. robusta males, a positive correlation among fast mating, repeat mating and fertlity was observed by Prakash (1967). In D. melanogaster, males with active esterase 6 mate sooner, copulate for a shorter duration and produce more progeny per mating as compared to esterase 6 null males at $16^{\circ} \mathrm{C}$ (Gilbert and Richmond, 1982). Thus the male mating propensity is an important component of fitness. It is evident from the present results that there is greater variation in mating activity of males than of females in all the populations studied. Thus a striking sax difference exists in $D$. ananassae. Spiess (1970) suggested that the set of polygenes necessary for efficient mating in one $\bar{s}$ ex is different from the set in the other sex. The striking sex difference observed during the present stuciy substantiates the above suggestion. Furthermore, the results also provide evidence that males are inherently more subject to intrasexual selection than females.

The present results on mating propensity of inversion karyotypes of $D$. ananassae demonstrate that the males with different karyotypes show considerable differences in mating activity. The females with different karyotypes also differ in sexual activity but variation is much reduced compared to males. Furthermore, the populations of $D$. ananassae vary in mating properties. In Ghazipur population, the males heterozygous for inversion have greater mating activity than the two homozygotes, which provides evidence for the existence of heterosis (cf. Spiess et al., 1966). However, the heterozygous males liave mating propensity nearly equal to one of the two homozygotes in other populations. Thus there is evidence of 
interpopulation variation with respect to mating activity of homo- and heterokaryotypes in $D$. ananassae. This is attributable to the variation in genic contents of the same chromosome in different populations which is further supported by the significant differences between ST/ST and AL/AL homozygotes in different populations.

Acknowledgement We thankfully acknowledge the financial support from the Department of Science and Technology, Government of India, New Delhi.

\section{REFERENCES}

BASTOCK, M. 1956. A gene mutation which changes a behaviour pattern. Evolution, 10, 421-439.

Bateman, A. J. 1948. Intra-sexual selection in Drosophila. Heredity, 2, 349-368.

BOSIGER, E. 1962. Sur le degre d'heterozygotie des populations naturalles de Drosophila melanogaster et son maintein parla selection sexuelle. Bull. Biologique, 96, 3-122.

BRNCIC, D. AND KOREF-SANTIBANEZ, S. 1964. Mating activity of homo- and heterokaryotypes in Drosophila pavani. Genetics, 49, 585-591.

EHRMAN, L. 1966. mating success and genotype frequency in Drosophila. Animal Behaviour, 14, 332-339.

EHRMAN, L. 1970. The mating advantage of rare males in Drosophila. Proc. Nat. Acad. Sci., 65, 345-348.

EHRMAN, L. AND PETIT, C. 1968. Genotype frequency and mating success in the Willistoni species group of Drosophila. Evolution, 22, 649-658

FUTCH, D. G. 1966. A study of speciation in South Pacific Populations of Drosophila ananassae. Univ. Texas Publ. $6615,79-120$.

GILBERT, D. G. AND RICHMOND, R. C. 1982. Esterase 6 in Drosophila melanogaster: Reproductive function of active and null males at low temperature. Proc. Natl. Acad. Sci., 79, 2962-2966.

KAUL, D. AND PARSONS, P. A. 1965. The genotypic control of mating speed and duration of copulation in Drosophila pseudoobscura. Heredity, 20, 381-392.

KOJIMA, K. AND TOBARI, Y. N. 1969. Selective modes associated with karyotypes in Drosophila ananassae. II Heterosis and frequency dependent selection. Genetics, 63, 639-651.

MANNING, A. 1961. The effects of artificial selection for mating speed in Drosophila melanogaster. Animal Behaviour, 9, 82-92.

MORIWAKI, D., OHNISHI, M. AND NAKAJIMA, Y. 1956. Analysis of heterosis in populations of Drosophila ananassae. Cytologia (Suppl. Vol.), 370-379.

PARSONS, P. A. 1973. Behavioural and ecological genetics: A Study in Drosophila. Clarendon Press, Oxford.

PARSONS, P. A. AND KAUL, D. 1966. Mating speed and duration of copulation in Drosophila psuedoobscura. Heredity, 21, 219-225.

PETIT, C. 1958. Le determinisme genetique et paychophysiologique de la competition sexuelle chez Drosophila melanogaster. Bull. Biol. Fr. Belg., 92, 248-329.

PRAKASH, S. 1967. Association between mating speed and fertility in Drosophila robusta. Genetics, 57, 655-663.

PRAKASH, S. 1968. Chromosome interactions affecting mating speed in Drosophila robusta. Genetics, 60, 589-600.
RENDEL, J. M. 1944. The genetics and cytology of Drosophila subobscura. J. Genet., 46, 287-302.

SHIRAI, M. AND MORIWAKI, D. 1952. Variations in gene sequences in various strains of Drosophila ananassae. Dros. Inf. Serv., 26, 120-121.

SINGH, B. N. 1970. Distribution of most common inversions of Drosophila ananassae in different parts of India including Andaman and Nicobar Islands. Ind. Biol., 2, 78-81.

SINGH, B. N. 1972. The lack of evidence for coadaptation in geographic populations of Drosophila ananassae. Genetica $43,582-588$.

SINGH, B. N. 1974. Quantitative variation of chromosomal polymorphism in natural populations of Drosophila ananassae. Cytologia, 39, 309-314.

SINGH, B. N. 1981. Interracial hybridization in Drosophila ananassae. Genetica 57, 139-142.

SINGH, B. N. 1982. Persistence of chromosomal polymorphism in various strains of Drosophila ananassae. Genetica 59, 151-156.

SINGH, B. N. $1983 a$. An inversion within the subterminal inversion in Drosophila ananassae. Experientia 39, 99-100.

SINGH, B. N. 1983b. Cosmopolitan inversions in Drosophila ananassae. Caryologia 36, 333-343.

SINGH, B. N. 1984a. Genetic differentiation in natural populations of Drosophila ananassae. Genetica, 63, 49-52.

SINGH, B. N. 1984b. High frequency of cosmopolitan inversions in natural populations of Drosophila ananassae from Kerala, South India. J. Heredity, 75, 504-505.

SINGH, B. N. 1984 c. Genetic distance in inversion polymorphism among natural populations of Drosophila ananassae. Genetica, 64, 221-224.

SINGH, B. N. $1985 a$. Genetic similarity between natural populations of Drosophila ananassae from Kerala and Andaman and Nicobar Islands. Genetica, in press.

SINGH, B. N. $1985 b$. Genetic differentiation at the level of chromosomal polymorphism in Indian populations of Drosophila ananassae (unpublished).

SINGH, B. N. 1985c. Heterosis without selectional coadaptation in Drosophila ananassae. Theor. Appl. Genet., 69, 437-441.

SINGH, B. N. AND RAY-CHAUDHURI, S. P. 1972. Balanced chromosomal polymorphism in experimental populations of Drosophila ananassae. Ind. J. Exp. Biol., 10, 301-303.

SMith, J. M. 1958. Sexual selection. Barnett, S. A. (ed.) In $A$ century of Darwin, London, Heinemann, pp. 231-244.

SPERLICH, D. 1966. Unterschiedliche Paarungsaktivitat innerhalb und zwischen verschiedensen geographischen Stammen von Drosophils subobscura. Z. Verebungsl., 98, 10-15.

SPIESS, E. B. 1970. Mating propensity and its genetic basis in Drosophila. Hecht, M. K. and Steere, W. C. (eds.), In Essays in evolution and Genetics in honour of Theodosius Dobzhansky, Appleton- Century Crofts, New York, pp. 315379.

SPIESS, E. B. AND LANGER, B. 1961. Chromosomal adaptive polymorphism in Drosophila persimilis. III Mating propensity of homokaryotypes. Evolution, 15, 535-544.

SPIESS, E. B. AND LANGER, B. 1964a. Mating speed control by gene arrangement carriers in Drosophila persimilis. Evolution, $18,430-444$.

SPIESS, E. B. AND LANGER, B. 1964b. Mating speed control by gene arrangements in Drosophila pseudoobscura homokaryotypes. Proc. Natl. Acad. Sci. U.S.A. 51, 1015-1019.

SPIESS, E. B., LANGER, B. AND SPIESS, L. D. 1966. Mating control by gene arangements in Drosophila pseudoobscura. Genetics, 54, 1139-1149.

SPIETH, H. T. 1952. Mating behaviour within the genus Drosophila (Diptera). Bull. Am. Mus. Nat. Hist., 99, 401474. 